\title{
Diversity and mineral substrate preference in endolithic microbial communities from marine intertidal outcrops (Isla de Mona, Puerto Rico)
}

\author{
Estelle Couradeau $^{1,2}$, Daniel Roush ${ }^{1}$, Brandon Scott Guida $^{1}$, and Ferran Garcia-Pichel ${ }^{1}$ \\ ${ }^{1}$ School of Life Sciences, Arizona State University, 85282 Tempe, Arizona, USA \\ ${ }^{2}$ Laboratoire Biogéosciences, UMR6282, Université de Bourgogne, 21000 Dijon, France
}

Correspondence to: Ferran Garcia-Pichel (ferran@asu.edu)

Received: 16 June 2016 - Published in Biogeosciences Discuss.: 20 July 2016

Revised: 9 November 2016 - Accepted: 16 December 2016 - Published: 23 January 2017

\begin{abstract}
Endolithic microbial communities are prominent features of intertidal marine habitats, where they colonize a variety of substrates, contributing to their erosion. Almost 2 centuries worth of naturalistic studies focused on a few true-boring (euendolithic) phototrophs, but substrate preference has received little attention. The Isla de Mona (Puerto Rico) intertidal zone offers a unique setting to investigate substrate specificity of endolithic communities since various phosphate rock, limestone and dolostone outcrops occur there. High-throughput 16S rDNA genetic sampling, enhanced by targeted cultivation, revealed that, while euendolithic cyanobacteria were dominant operational taxonomic units (OTUs), the communities were invariably of high diversity, well beyond that reported in traditional studies and implying an unexpected metabolic complexity potentially contributed by secondary colonizers. While the overall community composition did not show differences traceable to the nature of the mineral substrate, we detected specialization among particular euendolithic cyanobacterial clades towards the type of substrate they excavate but only at the OTU phylogenetic level, implying that close relatives have specialized recurrently into particular substrates. The cationic mineral component was determinant in this preference, suggesting the existence in nature of alternatives to the boring mechanism described in culture that is based exclusively on transcellular calcium transport.
\end{abstract}

\section{Introduction}

In shallow and intertidal marine habitats, endolithic microbes colonize a variety of carbonaceous and phosphatic substrates, such as bone, shell, coraline carbonate, ooliths, limestones, dolostone and phosphorite outcrops (Campbell, 1983). Some of these microbes take advantage of the natural pores or crevices in the solids, but some have the ability to actively bore their way into the substrate. Such microborers, also known as euendoliths (Golubic et al., 1981), build communities that can cover as much as $50 \%$ of the exposed solid surface (Golubic et al., 2000) with full colonization times of virgin substrate on the order of months (Gektidis, 1999; Grange et al., 2015). Several long-term geological phenomena are driven by microborers, from the erosive morphogenesis of coastal limestones (Purdy and Kornicker, 1958; Schneider, 1983; Torunski, 1979; Trudgill, 1987) and the destruction of coral reefs and other biological carbonates (Le CampionAlsumard et al., 1995; Ghirardelli, 2002) to the formation of lithified laminae of welded carbonate grains in coastal stromatolites (MacIntyre et al., 2000; Reid et al., 2000). Additionally, phototrophic euendoliths can cause significant damage and shell weakening to bivalve populations (Kaehler and McQuaid, 1999). Long-term rates of microborer-driven carbonate dissolution, the "bioerosion" process, range between 20 and $930 \mathrm{~g} \mathrm{CaCO}_{3} \mathrm{~m}^{-2} \mathrm{~d}^{-1}$, of clear geologic significance (Grange et al., 2015; Peyrot-Clausade et al., 1995; Tudhope and Risk, 1985; Vogel et al., 2000) and may increase under future scenarios of increased atmospheric $\mathrm{CO}_{2}$ and ocean acidification (Tribollet et al., 2009). 
There exists a very large body of descriptive literature spanning 18 decades, largely based on microscopic observations, documenting the biodiversity of microborers, with contributions in the microbiological, ecological, sedimentological and paleontological fields (Acton, 1916; Al-Thukair et al., 1994; Bachmann, 1915; Batters, 1892; Bonar, 1942; Bornet and Flahault, 1888; Budd and Perkins, 1980; Le Campion-Alsumard et al., 1995; Chodat, 1898; Duerden, 1902; Duncan, 1876; Ercegovic, 1925, 1927, 1930; Frémy, 1936, 1941; Ghirardelli, 2002; Golubic, 1969; Kölliker, 1859; Lehmann, 1903; May and Perkins, 1979; Nadson, 1927; Pantazidou et al., 2006; Perkins and Tsentas, 1976; Wisshak et al., 2011). Euendoliths have been reported among eukaryotes (fungi, green and red algae) and prokaryotes (cyanobacteria), taxa where it may have been selected as a strategy to escape predation from grazers, protect from UV radiation or acquire nutrients as a tradeoff for the boring energetic cost (Cockell and Herrera, 2008). The most common genera of phototrophic eukaryotic euendoliths are Ostreobium and Phaeophila in the green algae, as well as the red algal genus Porphyra (in its filamentous diploid generation, known also as Conchocelis stage). In the cyanobacteria, the pseudofilamentous genera Hyella and Solentia are quite common (Al-Thukair, 2011; Al-Thukair et al., 1994; Al-Thukair and Golubic, 1991; Brito et al., 2012; Campion-Alsumard et al., 1996; Foster et al., 2009; Golubic et al., 1996), as are some forms in the simple filamentous genus Plectonema (Chacón et al., 2006; Pantazidou et al., 2006; Tribollet and Payri, 2001; Vogel et al., 2000). Morphologically complex cyanobacteria such as Mastigocoleus testarum (Golubic and Campion-Alsumard, 1973; Nadson, 1932; Ramírez-Reinat and Garcia-Pichel, 2012a) complete the list of common euendoliths. Less common genera of euendolithic cyanobacteria include Cyanosaccus (Pantazidou et al., 2006), Kyrtuthrix (Golubic and Campion-Alsumard, 1973) and Matteia (Friedmann et al., 1993). To date, these genera were all assigned based upon morphological criteria and could represent morphological variations of the same types (Le Campion-Alsumard and Golubic, 1985), highlighting the need to reassess the diversity of euendolithic cyanobacteria using a combination of characters including genetic markers.

Modern genomic methods for community fingerprinting have, more recently, been applied to provide a complementary and more comprehensive description of endolithic communities. Some studies, focused on phototrophs from marine carbonates, revealed that, while some biodiversity had been missed by deploying morphological studies, there was also congruency between DNA-based surveys and the traditional literature (Chacón et al., 2006; Ramírez-Reinat and GarciaPichel, 2012b). DNA-based studies have revealed that the endolithic habitat at large can harbor complex communities of microbes, in addition to euendoliths, particularly when the substrate rocks are naturally porous or when they have been rendered porous by the action of euendoliths themselves. Horath et al. (2006), for example, investigating terrestrial en- dolithic communities in dolomite outcrops in the Alps, found a large diversity of presumably chemotrophic bacteria and archaea, in addition to expected green algae and cyanobacteria. Similar conclusions could be drawn from the work of De la Torre et al. (De la Torre et al., 2003) on Antarctic sandstone cryptoendoliths, those of Walker and colleagues (Walker et al., 2005; Walker and Pace, 2007) on terrestrial limestones, sandstones and granites or the recent contribution of (CritsChristoph et al., 2016) who used a metagenomic approach to investigate the chasmoendolithic communities of the hyperarid Atacama Desert. However, no high-throughput sequencing studies are available on the globally significant intertidal endolithic communities.

Tribollet (2008) provided an account of the dynamic changes in microborer community composition taking place after coral death, which obviously constitute a true succession in the ecological sense, with pioneer euendoliths (such as Mastigocoleus testarum) and secondary colonizers such as Ostreobium quekettii and Plectonema terebrans, as well as fungi (Grange et al., 2015; Tribollet, 2008). During laboratory studies with the cultivated strain of Mastigocoleus testarum strain $\mathrm{BC} 008$, used as a model to understand the physiology of cyanobacterial boring (Garcia-Pichel et al., 2010; Guida and Garcia-Pichel, 2016; Ramírez-Reinat and Garcia-Pichel, 2012b), we found that, among the carbonates, this strain excavated most rapidly into various types of calcite and aragonite minerals $\left(\mathrm{CaCO}_{3}\right)$. It could bore slowly into strontianite $\left(\mathrm{SrCO}_{3}\right)$ but was unable to penetrate into magnesite $\left(\mathrm{MgCO}_{3}\right)$, dolomite $\left(\mathrm{CaMgCO}_{3}\right)$, witherite $\left(\mathrm{BaCO}_{3}\right)$, rhodochrosite $\left(\mathrm{MnCO}_{3}\right)$, siderite $\left(\mathrm{FeCO}_{3}\right)$ or ankerite $\left(\mathrm{CaFe}\left(\mathrm{CO}_{3}\right)_{2}\right.$; Ramírez-Reinat and Garcia-Pichel, 2012a). However, literature reports do exist detailing microborings in modern and fossil dolomitic substrates (see, e.g., Campbell, 1983; Golubic and Lee, 1999). Similar substrate preferences have also been observed for phosphates: M. testarum strain BC008 did not bore into calcophosphatic substrates, including hydroxyapatite, vivianite or dentine, yet the literature is replete with reports of cyanobacterial microborings on biotic and abiotic phosphatic rocks (Soudry and Nathan, 2000; Underwood et al., 1999; Zhang and Pratt, 2008). The expression of such a mineral substrate preference among the pioneer euendolithic cyanobacteria could principally drive the whole community towards a different successional sequence with distinct mature community assemblages and metabolic potentialities. We wanted to find out whether evolutionary specialization has resulted in a highly adapted endolithic flora for each type of mineral substrate and whether there exist specialized apatite-borers, dolomiteborers or carbonate-borers in nature.

In order to answer these questions, we investigated in depth the marine endolithic communities of Isla de Mona (PR), a small, uninhabited Caribbean island offering a variety of coastal cliffs composed of dolomite and limestone, as well as raised aragonitic and phosphatic reefs, with the dual purpose to (i) describe the microbial diversity of inter- 
tidal endolithic community at high resolution and (ii) test the effects of substrate composition on community structure in a single geographic location with common bathymetry (the intertidal notch), controlling for other known major determinants of community composition.

\section{Materials and methods}

\subsection{Sampling site and procedure}

Samples were obtained from Isla Mona $\left(18.0867^{\circ} \mathrm{N}\right.$, $\left.67.8894^{\circ} \mathrm{W}\right)$, a small $(11$ by $7 \mathrm{~km}$ ) carbonate island $66 \mathrm{~km} \mathrm{~W}$ of Puerto Rico. Isla Mona is a protected habitat and all necessary permits were acquired from the Departamento de Recursos Naturales y Ambientales prior to arrival. The present study did not involve endangered or protected species. Endolithic communities were obtained by sampling different locations from nine separate island localities. Rock samples containing endolithic biomass, verified using a digital field microscope, were chipped off from large boulders and rock walls using a standard geological hammer. The hammer was thoroughly washed with surrounding sea water at each sampling point. Material was predominantly collected within the boring notch of the intertidal zone. Bathymetric samples were collected via SCUBA diving at sample site $\mathrm{K}$ at depths of 3.5, 4.6, 7 and $9.1 \mathrm{~m}$. Each sample was broken into three pieces and each biological replicate was stored in a sterile $50 \mathrm{~mL}$ falcon tubes; one replicate was air dried for mineralogical analysis, one was kept viable in seawater for strain isolation and another was preserved in situ in $70 \%$ ethanol for DNA extraction. Air drying and alcohol preservation were done in the field. Samples were shipped at room temperature, in the dark for 5 days, and, upon arrival in the lab, the preserved samples were immediately stored at $-20^{\circ} \mathrm{C}$ until extractions were performed. Aliquots of local seawater were collected at sample site $\mathrm{K}$ and filtered through $0.22 \mu \mathrm{m}$ syringe filters into sterile $50 \mathrm{~mL}$ falcon tubes. After 5 days of transit at room temperature in the dark, the seawater sample was stored at $4{ }^{\circ} \mathrm{C}$ in the dark for an additional week before being processed for physicochemical analysis.

\subsection{Bulk powder X-ray diffraction and elementary analyses}

A fragment of each sample was ground down to powder in $100 \%$ ethanol. XRD patterns were collected using Panalytical X'Pert Pro diffractometer mounted in the DebyeScherrer configuration with a $\mathrm{CuK} \alpha$ monochromatic X-ray source. Data were recorded in continuous scan mode within a $10-90^{\circ} 2 \theta$ range. X'Pert High Score plus software was used to identify mineral phases and their relative concentration using the automatic Rietveld refinement method implemented in the software under default parameters. The elementary composition of the rocks and water sample analyses were performed by the Goldwater Center at Arizona State Uni- versity using an inductively coupled plasma optical emission spectrometer (ICP-OES), Thermo iCAP6300.

\subsection{Total genomic DNA purification}

The surface of the ethanol fixed samples was brushed vigorously with a sterile toothbrush and sterile Milli-Q water to remove epilithic material. A chip of $8 \mathrm{~cm}^{3}$ was further ground in a sterile mortar as recommended by Wade and GarciaPichel (2003); $0.5 \mathrm{~g}$ of the obtained coarse powder was then transferred into the bead tube of the MoBio PowerPlant Pro kit (Mo Bio Laboratories, Inc., Carlsbad, CA, USA). The first lysis step of the kit was modified by homogenizing bead tubes horizontally at $2200 \mathrm{rev} \mathrm{min}^{-1}$ for $10 \mathrm{~min}$ and seven freeze-thaw cycles (Wade and Garcia-Pichel, 2003). The next steps of the extraction were conducted following the MoBio PowerPlant Pro kit following manufacturer's guidelines.

\subsection{6s rRNA gene library preparation and sequencing}

The 16S rRNA gene V3-V4 variable region was targeted using PCR primers 341F (CCTACGGGNGGCWGCAG) and 806R (GGACTACVSGGGTATCTAAT) with a barcoded forward primer. The PCR amplification was performed using the HotStartTaq Plus Master Mix Kit (Qiagen, USA) under the following conditions: $94^{\circ} \mathrm{C}$ for $3 \mathrm{~min}$, followed by $28 \mathrm{cy}-$ cles of $94^{\circ} \mathrm{C}$ for $30 \mathrm{~s}, 53{ }^{\circ} \mathrm{C}$ for $40 \mathrm{~s}$ and $72^{\circ} \mathrm{C}$ for $1 \mathrm{~min}$, followed by a final $5 \mathrm{~min}$ elongation step at $72^{\circ} \mathrm{C}$. PCR product were further purified and pooled into a single DNA library using the Illumina TruSeq DNA library preparation protocol. This library was further sequenced on a MiSeq following the manufacturer's guidelines. The library preparation, sequencing paired ends assembly and first quality trimming (with phred score of Q25 cutoff) were performed by MR DNA (www.mrdnalab.com, Shallowater, TX, USA).

The 16S rDNA sequences from the newly cultured euendolithic strains were retrieved using the PCR condition and primers described by Nübel et al. (1997) followed by Sanger sequencing. Briefly, the primers used were the forward Cya106F (CGGACGGGTGAGTAACGCGTGA) and an equimolar mixture of the Cya781R(a) (GACTACTGGGGTATCTAATCCCATT) and Cya781R(b) (GACTAC AGGGGTATCTAATCCCTTT) as reverse. The PCR amplification was performed using the GoTaq enzyme and master mix (Promega, Madison, USA) at $1 \mathrm{X}$ concentration. The amplification conditions were as follows: after an initial denaturation step $94^{\circ} \mathrm{C}$ for $5 \mathrm{~min}, 35 \mathrm{PCR}$ amplification cycles were performed, each consisting of a 1 min denaturation step at $94^{\circ} \mathrm{C}$, a $1 \mathrm{~min}$ annealing step at $60^{\circ} \mathrm{C}$ and a $1 \mathrm{~min}$ elongation step at $72{ }^{\circ} \mathrm{C}$. 


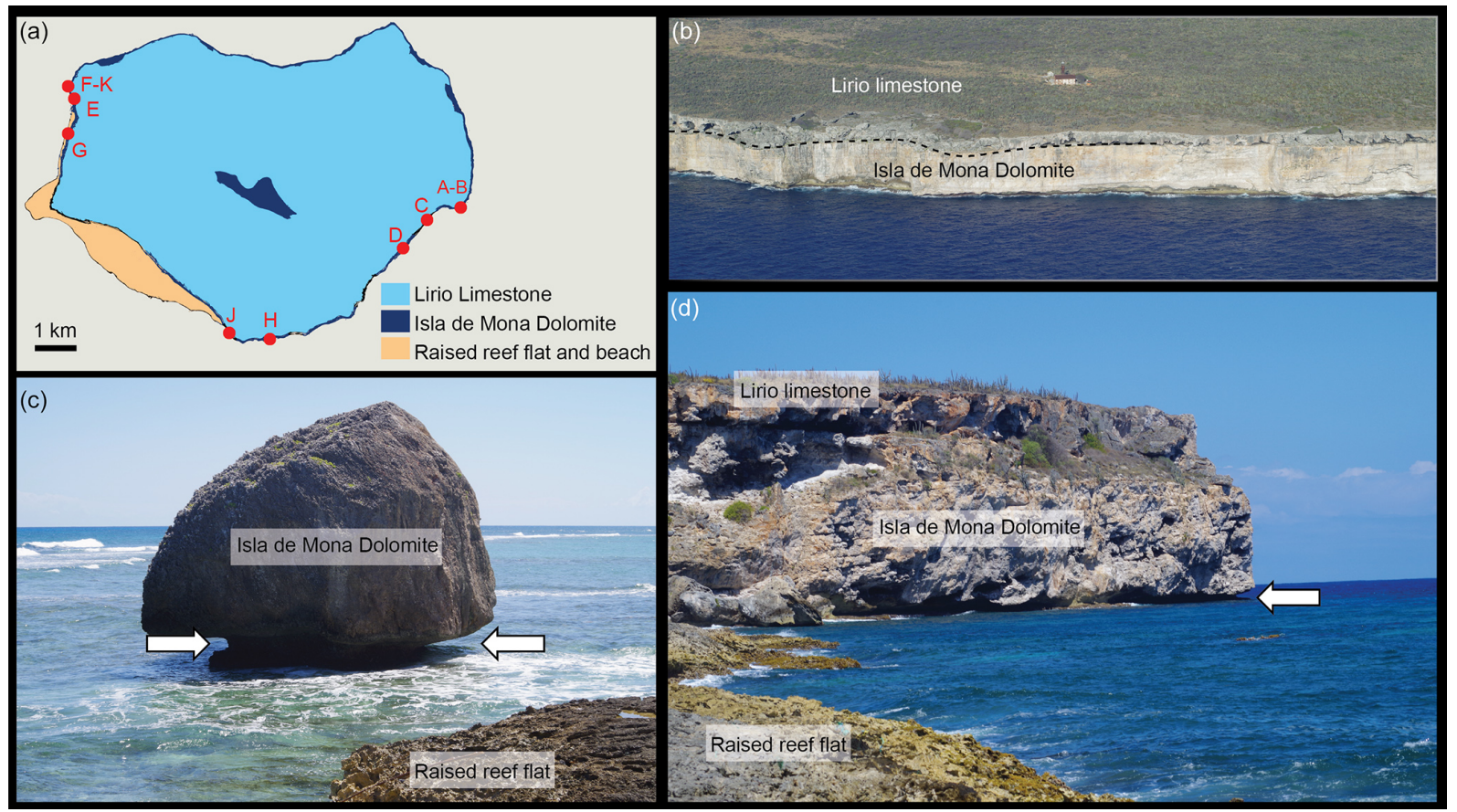

Figure 1. Isla de Mona setting: (a) simplified geological map modified from that of Briggs and Seiders (1972), showing the locations of the sampling sites. (b) Sky view of Isla de Mona: the cliff is composed of the Isla de Mona Dolomite topped by the Lirio limestone and the Isla de Mona lighthouse is visible. (c-d) Views of Isla de Mona coastal area: samples were taken from isolated boulders (c) and directly from the cliff $(\mathbf{d})$, at the notch (white arrows $\mathbf{c}-\mathbf{d})$ or on the raised reef flat $(\mathbf{c}-\mathbf{d})$.

\subsection{Operational taxonomic unit (OTU) table building and analysis}

Sequences were further processed using the Qiime version 1.9 (Caporaso et al., 2010). The sequences were first run through the split_libraries.py script under the default parameter that includes barcode removal, quality filtering (sequences of less than $200 \mathrm{bp}$ or with homopolymer runs exceeding $6 \mathrm{bp}$ were removed) and split of the dataset per sample. The output file was further processed through the pick_open_reference_otus.py script using the default parameters except for the taxonomic assignment that was done by the RDP classifier (see parameter file in Supplement for more details). This step clustered the sequences at a similarity threshold of $97 \%$ (Edgar, 2010) to build OTUs, assign their taxonomy and further report specific abundance for each sample into an OTU table. Because in this case we were not interested into the rare biosphere but focused on the most abundant OTUs and how they vary, we filtered the OTU table to remove the rare OTUs. The OTUs retained were those that occurred in at least 5 samples among the 34 analyzed or that represent more than $0.1 \%$ of the total sequences found in a particular sample. By doing this, we eventually analyzed $90 \%$ of all the single sequences but only $11 \%$ of the initial OTUs. The Qiime script summarize_taxonomy_through_plots.py was run on the final OTU table for all the prokaryotes and for the cyanobacteria only (filtering out the chloroplasts) in order to build the summarized microbial community composition bar graphs displayed in Fig. 2.

\subsection{Accession numbers}

One representative sequence per OTU was deposited to gene bank under the accession numbers KT972744-KT981874. The 16S rDNA sequences of the new euendolithic strains described in this article received the following accession numbers: $C a$. Pleurinema perforans IdMA4 [KX388631], $\mathrm{Ca}$. Mastigocoleus perforans IdM [KX388632] and Ca. Pleurinema testarum RPB [KX388633].

\subsection{Meta-analysis of microbial communities}

For comparison, raw sequences from datasets ID 662/678/809/627/713/925 were retrieved from the Qiita repository along with their mapping table. All these studies used comparable sequencing depth, technology and targeted the same region of the 16 rRNA gene compared to the present study. Two samples from Alchichica cyanobacteriadominated microbialites communities (Couradeau et al., 2011) were processed in parallel to the Isla de Mona samples (same extraction methodology, sequenced in the same MiSeq run) and also included in this analysis. The sequences were all aggregated into a master file that was processed in Qiime version 1.9 (Caporaso et al., 2010). The same exact proce- 


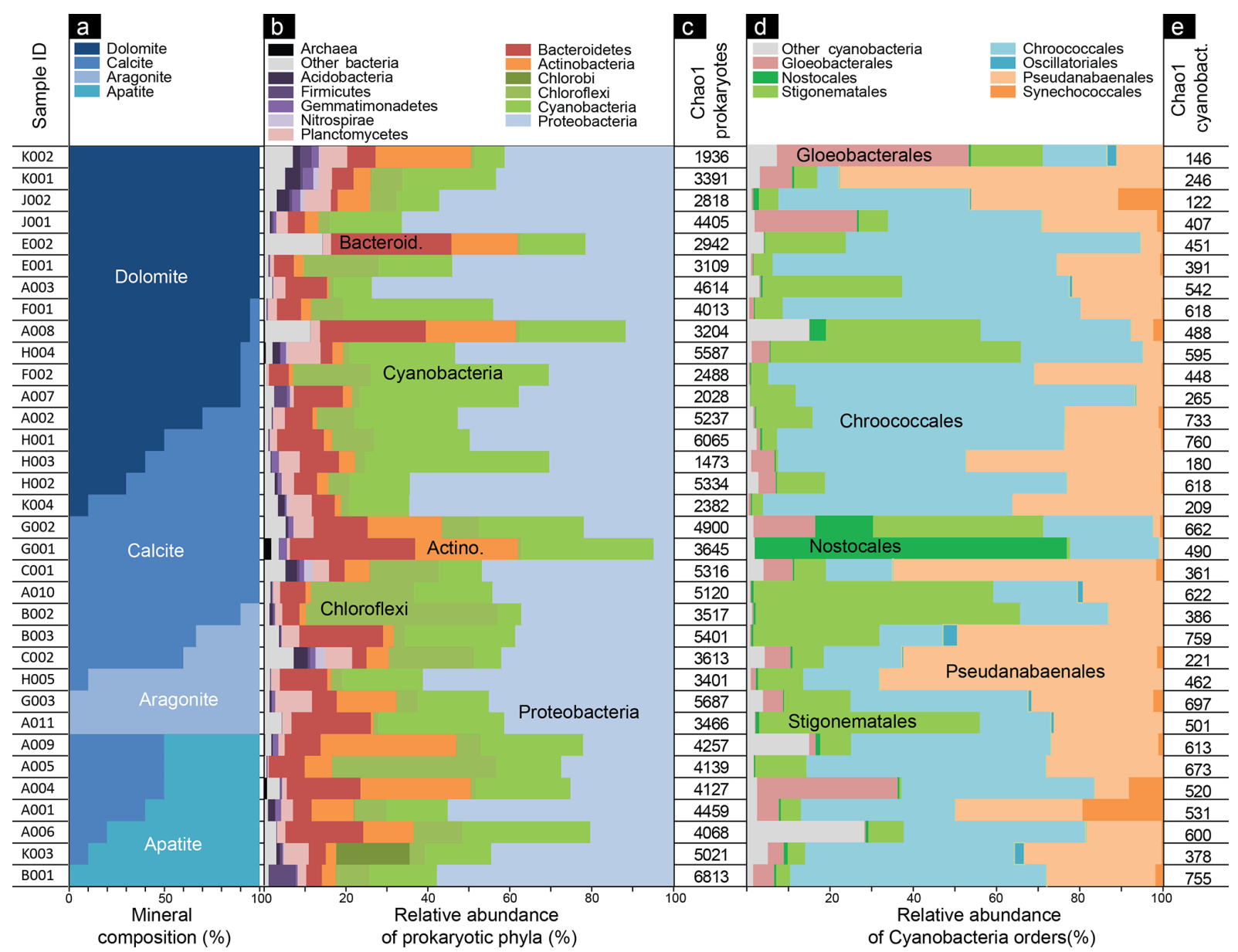

Figure 2. Mineral composition and microbial community structure of Isla de Mona intertidal outcrops. Each line corresponds to one sample. (a) Mineralogical composition as retrieved by bulk powder XRD. (b) Distribution of 16 rDNA OTUs taxonomically assigned at the phylum level and (c) associated chao1 richness metric. This reflects the total microbial community structure. (d) Distribution of the cyanobacterial 16 rDNA OTUs assigned at the phylum level, excluding chloroplasts and associated chao1 richness metric for cyanobacteria (e).

dure than the one described above was used to pick OTUs. Again we retained the OTUs that occurred at least in five samples. We ran the jackknifed_beta_diversity.py pipeline using the Bray-Curtis metrics under default parameters. The obtained distances were used to cluster samples under a UPGMA hierarchical clustering method and 5000 sequences were included in each jackknifed subset in order to generate nodes support.

\subsection{Differential abundance of OTUs analyses}

To determine if some OTUs were more associated with certain type of substrates we ran the differential_abundance.py of the Qiime 1.9 package (Caporaso et al., 2010) using the DESeq2 method (Love et al., 2014), under a negative binomial generalized linear model. This method was initially developed to assess the differential gene expression from RNAseq data but can be applied to any count matrix data such as OTU tables (Love et al., 2014). It was recently imple- mented for the treatment of 16S rDNA OTU table and has been widely used since (e.g., Debenport et al., 2015; Pitombo et al., 2015) because it (i) is a sensitive and precise method, (ii) controls the false positive rate (Love et al., 2014) and (iii) uses all the power of the dataset without the need to rarefy the OTU table (McMurdie and Holmes, 2014). After checking the good agreement between the fit line and the shrunken data on the dispersion plot, a Wald test was applied to each OTU to reject the null hypothesis $(p<0.05)$ because the logarithmic fold change between treatments (i.e., in our case type of mineral substrate) for a given OTU is null.

\subsection{Phylogeny reconstruction}

In order to determine which of the cyanobacterial OTUs of the dataset were possible euendolithic organisms, we built a phylogeny to assess their proximity to proven boring cultured strains. The maximum-likelihood phylogenetic reconstruction was performed using TREEFINDER (Jobb et al., 2004) 
under a general time reversible (GTR) and a four-category discrete approximation of a $\Gamma$ distribution. Bootstrap values were inferred from 1000 replicates. The sequence dataset used for the reconstruction was first aligned with MAFFT (Katoh et al., 2005) and then manually checked and trimmed using the MUST package (Philippe, 1993).

\section{Results and discussion}

\subsection{Geological setting of Isla de Mona outcrops}

The island is an 11 by $7 \mathrm{~km}$ emerged platform of Miocene Isla de Mona Dolomite (up to $80 \mathrm{~m}$ thick) topped by a thinner (up to $40 \mathrm{~m}$ ) layer of Miocene Lirio limestone (Briggs and Seiders, 1972; Frank et al., 1998). It is partially surrounded in its southern and southwestern shores by a Pleistocene raised reef flat, mostly composed of biogenic carbonates (Fig. 1). The island also harbors secondary phosphorite deposits formed by the diagenetic alteration of guano, most typically associated with an extensive system of karstic caves at the interface of limestone and dolostone (Briggs, 1959). Isla de Mona was never continuously inhabited. The island was mostly used as a guard post over the Mona Passage throughout the 20th century, and declared a nature preserve in 1993 (National Parks Register, USA). The coastal area has been protected from disturbance ever since. We took advantage of this unique and pristine geological setting to sample dolostones, limestones and phosphorites exposed to similar environmental conditions. We analyzed a set of 34 samples consisting of pieces of exposed rock, in most cases taken directly at the intertidal notch. Location of sampling sites are in the simplified geological map in Fig. 1a. The mineralogical composition of each sample (Fig. 2), determined using bulk powder $\mathrm{X}$-ray diffraction, confirmed the presence of apatite $\left(\mathrm{Ca}_{5}\left(\mathrm{PO}_{4}\right)_{3}(\mathrm{OH}, \mathrm{Cl}, \mathrm{F})\right)$, dolomite $\left(\mathrm{CaMg}\left(\mathrm{CO}_{3}\right)_{2}\right)$, calcite $\left(\mathrm{CaCO}_{3}\right)$ and aragonite $\left(\mathrm{CaCO}_{3}\right)$ in various proportions depending of the sampling site (Fig. 2a).

\subsection{The endolithic microbial communities}

We studied the endolithic community composition by analyzing the $16 \mathrm{~S}$ rDNA diversity present in total genomic DNA extracted from the rock after aggressively brushing away epilithic growth from the external sample surface. The 16S rDNA sequences were obtained after specific PCR amplification and Illumina-based high-throughput sequencing, with one library per sample (Table S2 in the Supplement). We clustered sequences into OTUs based on a $97 \%$ similarity criterion and further filtered the dataset to remove the rare OTUs, focusing our study on OTUs that occurred in at least five separate samples or those that made up more than $0.1 \%$ of all sequences in any one sample. Bacterial OTU richness in these samples was $4058 \pm 1252$, as given by the chao1 metric (Fig. 2c). Thus, comparatively our endolithic communities are of rather low diversity, an order of magnitude lower than current estimates assigned to bulk soil bacterial communities (Roesch et al., 2007), but similar to other microbial communities such as biological soil crusts (Couradeau et al., 2016), microbial mats (Hoffmann et al., 2015) or stromatolites (Mobberley et al., 2011) that are dominated by cyanobacterial primary producers. This suggests that endolithic habitat nurtured by the presence of cyanobacterial primary producers can support the development of a high diversity of microorganisms even when this type of habitat is expected to be nutrient limited due to its low connectivity with sea water (Cockell and Herrera, 2008). Taxonomic assignment of the OTUs on the basis of the Greengene database (McDonald et al., 2012) allowed us to reconstruct the endolithic prokaryotic communities from Isla de Mona at various level of taxonomic resolution. At the phylum level (Fig. 2b), the analysis revealed complex microbial communities with numerically significant populations of bacteria other than cyanobacteria: Proteobacteria, Chloroflexi, Actinobacteria and Bacteroidetes. In fact, the contribution of cyanobacteria to the total sequence richness was only $12 \pm 3 \%$. These communities clearly host not only a large number of bacterial types but also a wide diversity of phylogenetic and metabolic potential beyond oxygenic photosynthesis. Clearly, mature endolithic cyanobacterial communities in this study are much more complex than the majority of the literature to date (for example, the exhaustive descriptive literature review in the introduction does not report beyond cyanobacteria and eukaryotic algae). While it is proven that some axenic cyanobacteria are able to initiate excavation on virgin substrate (Ramírez-Reinat and Garcia-Pichel, 2012a), it is interesting to entertain that in such complex communities, other metabolic activities (of co-occurring microorganisms), particularly those that result in $\mathrm{pH}$ changes, might play a significant role on the determination of the local saturation index of the carbonate mineral (Baumgartner et al., 2006; Dupraz et al., 2009; Dupraz and Visscher, 2005) and in this way influence the overall mineral excavation yield or rates. At this level of taxonomic resolution, we did not detect any significant association of substrate mineralogy and community composition (as judged by nonsignificant Spearman's $\rho$ when comparing each phylum's relative abundance to mineralogical composition; not shown).

Because endolithic communities have not received much attention, we integrated our dataset into a meta-analysis of various cognate microbial communities, for which technically comparable datasets were publicly available (http: //qiita.microbio.me). To do so, we aggregated all the sequences from the selected Qiita datasets into a single file that was used to pick and cluster 16S rDNA OTUs anew and conducted similarity analyses. The meta-community analysis revealed that endolithic communities clustered together and apart from other types of phototrophic microbial communities in terms of composition (beta-diversity). The fact that they clustered together indicates that their microbial assemblages are recognizable and distinct beyond just their be- 
Table 1. Euendolithic cyanobacterial strains used to assign potential roles to OTUs.

\begin{tabular}{|c|c|c|c|c|c|c|}
\hline Strain name & Order & $\begin{array}{l}\text { Reference } \\
\text { sequence }\end{array}$ & $\begin{array}{l}\text { presence in } \\
\text { this dataset }\end{array}$ & Isolation source & $\begin{array}{l}\text { Bores in culture } \\
\text { culture }\end{array}$ & Reference \\
\hline Mastigocoleus testarum & Stigonematales & DQ380405 & yes & $\begin{array}{l}\text { Cabo Rojo carbonate, } \\
\text { Puerto Rico }\end{array}$ & yes & Chacón et al. (2006) \\
\hline Solentia sp. HBC10 & Pleurocapsales & EU249126 & no & Stromatolite bahamas & yes & Foster et al. (2009) \\
\hline Hyella sp. LEGE 07179 & Pleurocapsales & HQ832901 & yes & $\begin{array}{l}\text { Rocky Moledo do } \\
\text { Minho beach (Portugal) }\end{array}$ & not tested* & Brito et al. (2012) \\
\hline Ca. Pleurinema perforans IdMA4 & Pleurocapsales & KX388631 & yes & Isla de Mona outcrop & yes & this study \\
\hline $\mathrm{Ca}$. Mastigocoleus perforans IdM & Stigonematales & KX388632 & yes & Isla de Mona outcrop & yes & this study \\
\hline $\mathrm{Ca}$. Pleurinema testarum RPB & Pleurocapsales & KX388633 & Yes & $\begin{array}{l}\text { Puerto Peñasco } \\
\text { Coquina reef }\end{array}$ & yes & this study \\
\hline
\end{tabular}

* Hyella sp. LEGE 07179 was isolated from inside a patella shell where it was identified as a true borer by the authors but its boring ability was never tested again in the lab.

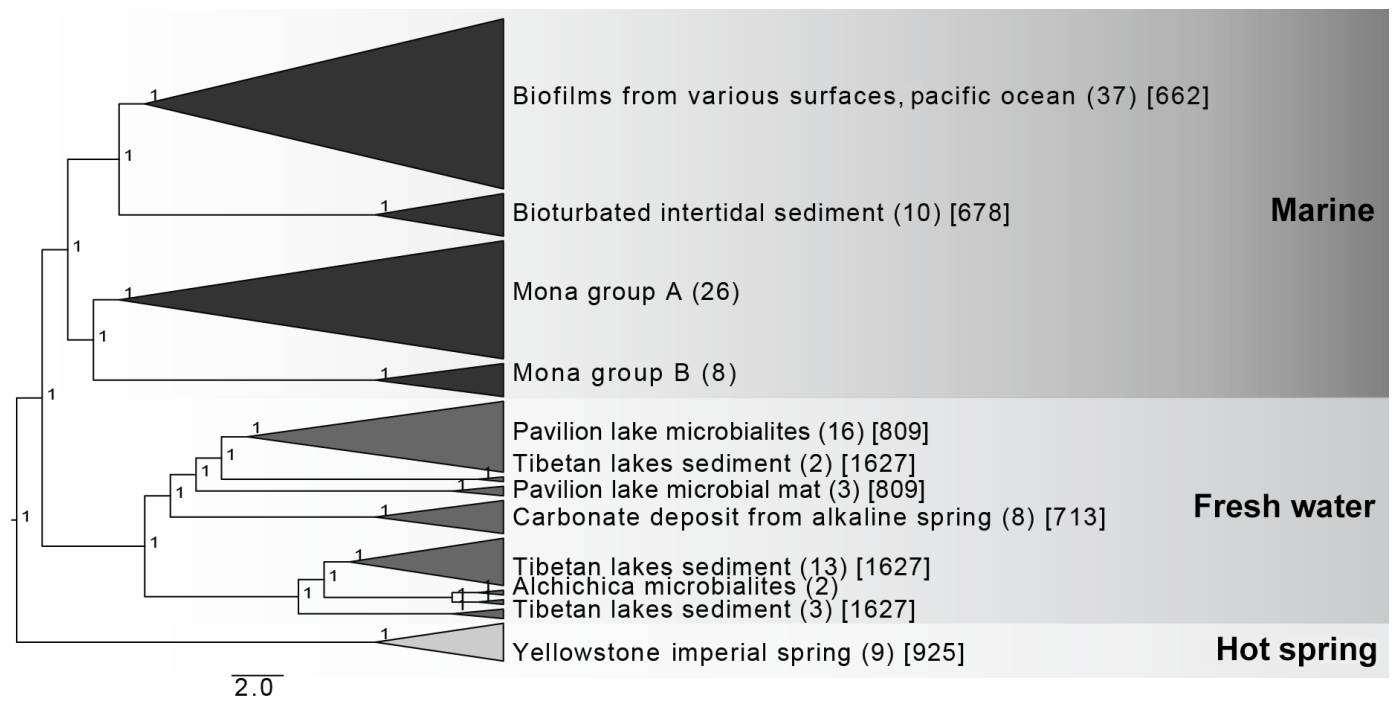

Figure 3. Hierarchical clustering analysis (UPGMA) of bacterial community composition in various settings based on pairwise Bray-Curtis distance metrics. The robustness of the topology was assessed through jackknife repeated resampling of 5000 sequences. The number of samples in a given collapsed tree branch are in parentheses, while the numbers in brackets are the Qiita dataset ID number.

longing to the marine habitat itself, in a microbiological and presumably adaptive way. However, at this stage we cannot exclude that the observed pattern could represent a biogeographical island effect. Further studies involving a larger dataset of endolithic communities will be necessary to disentangle the local signature controlled by environmental parameters from the endolithic signature presumably universal to all endolithic communities. Interestingly, our endolithic community samples could be separated into two self-similar clades (A and B in Fig. 3) but so far we cannot ascertain a factor that would drive the observed separation beyond the fact that it is not substrate type. While it would be of interest to compare our communities to other endolithic communities, such as those studied by Chacón et al. (2006), CritsChristoph et al. (2016), Horath and Bachofen (2009) and De la Torre et al. (2003), this is not technically possible given that all of those studies used alternative methods for commu- nity analyses (Clone libraries, DGGE, metagenomes) that do not allow direct comparisons.

\subsection{A diverse cyanobacterial community dominated by likely euendoliths}

Because they comprise the pioneer microborers and primary producers within many endolithic communities, cyanobacteria are of particular interest in this study. We therefore analyzed cyanobacteria at a higher resolution. The cyanobacterial community appeared quite diverse with a specific chao1 richness of $484 \pm 184$, certainly much more genetic diversity among this group than could be surmised from the wealth of microscopically based accounts in the botanical literature (Chazottes et al., 1995; Pantazidou et al., 2006; Sartoretto, 1998; Tribollet et al., 2006). In these studies, one typically finds reports of anywhere from one to five morphotypes. Even accounting for the fact that morphotypes typically underestimate genetic diversity by a significant fraction 
(Nübel et al., 1999), this is a very large underestimation of oxygenic phototroph diversity. Phylotypes assignable to the orders Pseudanabaenales, Chrooccocales, Nostocales and Stigonematales were most common and widespread. Again, no pattern linking mineralogy to microbial community composition arose at this taxonomic level, as judged by the nonsignificant Spearman's $\rho$ when comparing the relative abundance of each cyanobacterial to mineralogical composition (not shown). A combination of literature search and additional efforts of cultivation and genetic characterization of isolates allowed us to attempt the assignment of a true-boring (euendolithic) role to some of our cyanobacterial OTUs (Table 1 and Figs. S2-S3 in the Supplement). Interestingly, out of the five most abundant OTUs in our combined dataset, four (NR_OTU741, OTU 842393, NR_OTU193 and OTU 351529) could be deemed as likely euendoliths, given their close phylogenetic affiliation to cultivated isolates proven in the laboratory to be able to bore. The fifth most abundant OTU (OTU 186537) fell between Mastigocoleus testarum BC008 (a proven euendolith) and Rivularia atra (not described as boring in the literature), so its capacities remain unclear. Notably, the most abundant OTU, NR_OTU741 in our set is virtually indistinguishable from one of our isolates obtained from the same samples, the boring strain $\mathrm{Ca}$. Pleurinema perforans IdMA4 (similarity $>99 \%$ ), which is not only the most abundant cyanobacterial OTU but also the second most abundant bacterial OTU overall in our dataset. Overall the seven OTUs that could be assigned as possible euendolith based on their phylogenetic proximity to known microborers account for 0.8 to $73 \%$ (average value $29 \%$ ) of the total number of sequences depending on the sample considered. These results suggest that euendoliths compose a major fraction of the community, one that not only represents an initial set of pioneers but also maintains relevance even after bioerosive degradation and reworking of the mineral substrates allow the colonization of newly made pore spaces by non-boring endoliths.

On analyzing the diversity of the possible euendoliths detected in this dataset, we realized that while many of the most common known genera of cyanobacterial microborers are represented and abundant, the thin, filamentous Plectonema terebrans is not. This was surprising because Plectonema terebrans has always been described as an important member of the euendolithic community, accounting for up to $80 \%$ of the total of microborer biomass (Tribollet, 2008), and is found associated with Mastigocoleus testarum. This apparent paradox is likely not due to the absence of the organism but rather to failure to properly identify it molecularly due to the lack of reference sequences in the databases. Indeed morphotypes resembling Plectonema terebrans were visually recognized but not detected molecularly in the extensive study of euendolithic cyanobacteria from various locations by (Ramírez-Reinat and Garcia-Pichel, 2012b). In the present dataset, Plectonema could have been assigned to another member of the Oscillatoriales, such as Phormidium or

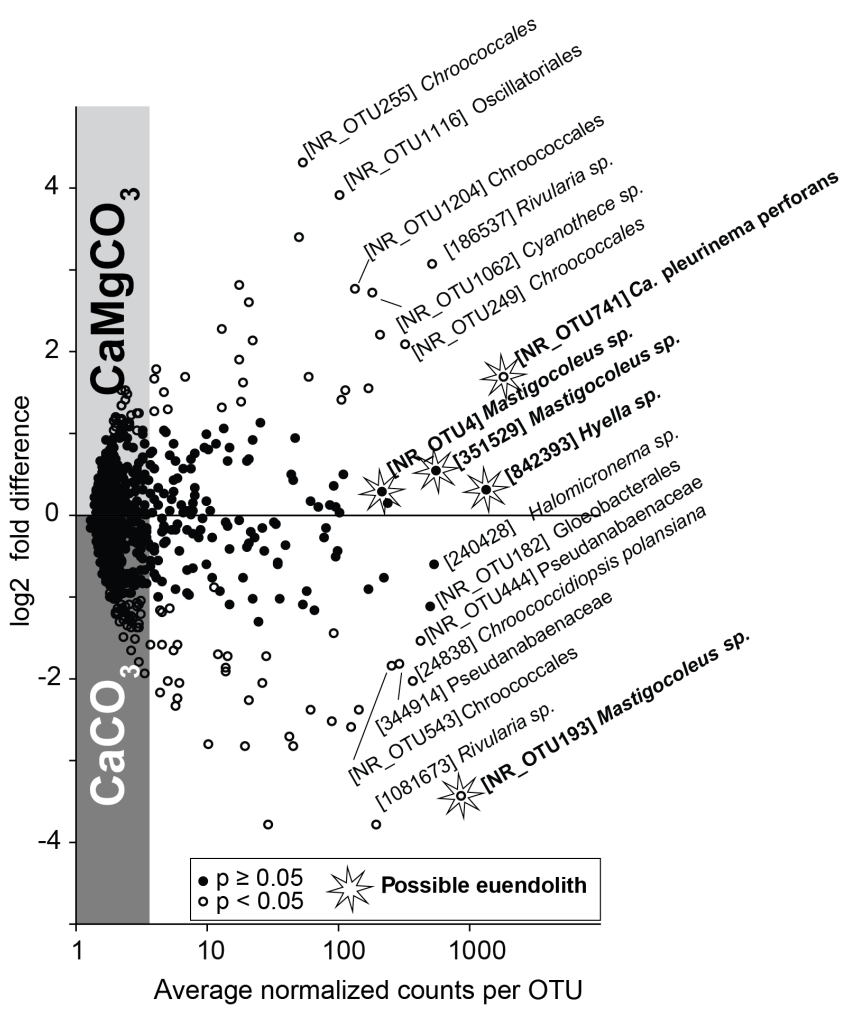

Figure 4. Differential abundance of cyanobacterial OTUs in Ca carbonates (calcite-aragonite) $n=14$ vs. CaMg carbonate (dolomite) $n=13$ samples. This plot was constructed using the DESeq2 method. It displays the average normalized counts per OTU as a measure of abundance against the $\log 2$ fold difference. The OTUs that were significantly differentially abundant in the two conditions $(p<0.05)$ are represented as open circles; the other ones are displayed as close symbols. Positive values indicate enrichment towards $\mathrm{CaMg}$ carbonate and negative values indicate enrichment towards $\mathrm{Ca}$ Carbonate. The OTU ID and taxonomical assignment of the most abundant OTUs is displayed on the right. The stars tag the possible euendolithic OTUs as determined by phylogenetic proximity to known microborers (Fig. S3).

Halomicronema, which represent 10 and $4.6 \%$, respectively, of the cyanobacterial sequences. A bona fide isolate proven to bore in the lab will be needed before we can advance regarding the presence and abundance of simple filamentous euendolithic cyanobacteria anywhere. Among the cyanobacterial taxa detected, the following have never been reported to be true borers: Gloeobacterales, Nostocaceae, Acaryochlorales, Cyanobacteriaceae, Spirulinaceae and Pseudanabaenales. In all, these cyanobacteria contribute at least to some $43 \pm 20 \%$, indicating that a significant proportion of the community is likely made up of adventitious endoliths. A study of the temporal dynamics of colonization could help understand the true role of each taxon. 


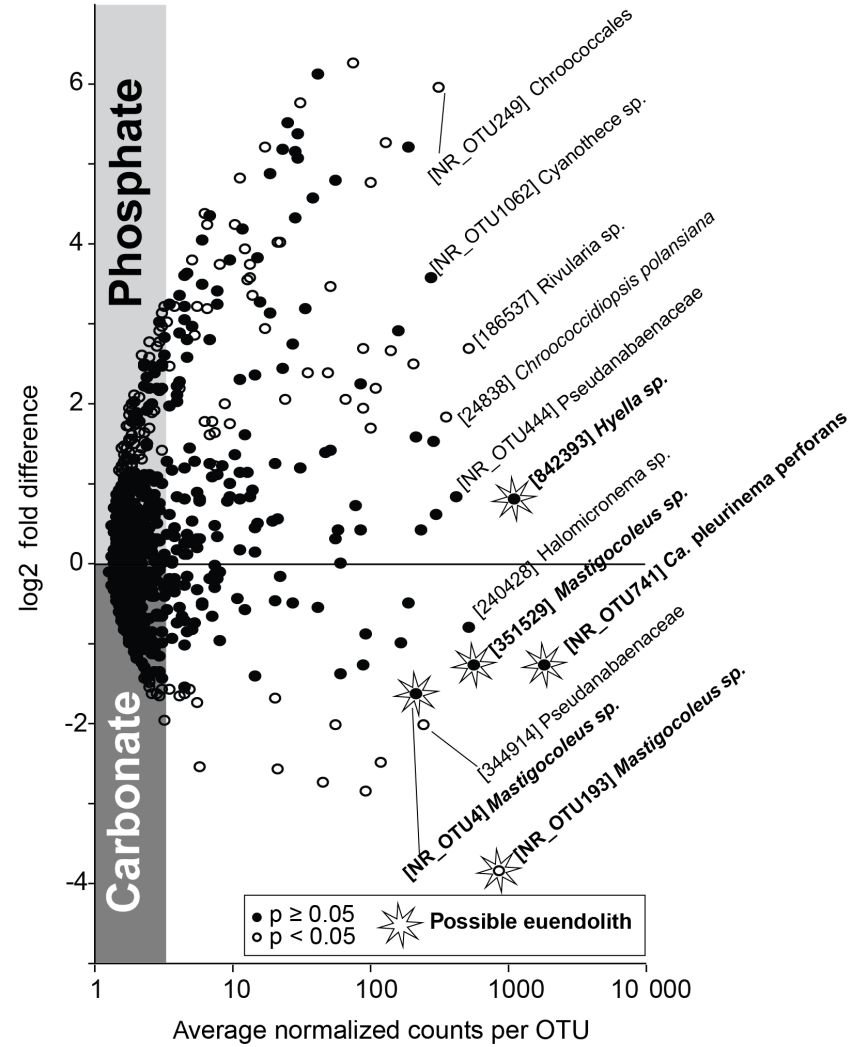

Figure 5. Differential abundance of cyanobacterial OTUs in Ca carbonate (calcite-aragonite) $n=14$ vs. Ca phosphate (apatite) $n=3$ samples This plot was constructed using the DESeq 2 method. It displays the average normalized counts per OTU as a measure of abundance against the $\log 2$ fold difference. The OTUs that were significantly differentially abundant in the two conditions $(p<0.05)$ are represented as open circles; the other ones are displayed as close symbols. Positive values indicate enrichment towards Ca phosphate and negative values indicate enrichment towards $\mathrm{Ca}$ Carbonate. The OTU ID and taxonomical assignment of the most abundant OTUs is displayed on the right. The stars tag the possible euendolithic OTUs as determined by phylogenetic proximity to known microborers (Fig. S3).

\subsection{Substrate preference among cyanobacteria}

We knew from the experimental study of the model euendolith Mastigocoleus testarum strain BC008 that this particular organism exhibits a clear boring substrate preference. It bores into $\mathrm{Ca}$ carbonates (like aragonite and calcite) and to a lesser extent $\mathrm{Sr}$ carbonate (strontianite), but not into $\mathrm{CaMg}$ carbonate like dolomite (Ramírez-Reinat and Garcia-Pichel, 2012a). This strain remains the single case where the boring preference has been directly tested, but it is unknown whether this preferential behavior is representative of euendoliths at large. Only a few studies examined endolithic communities colonizing dolostone; Jones (1989) provided the first comparison of endolithic communities from dolostones and limestones from Grand Cayman Ironshore. He ob- served that dolostones were less colonized by endoliths than limestones and concluded that the bioerosion of limestones was faster due to the more abundant endolithic flora, while the erosion pattern of the dolostone was slower and allowed the development of more epiliths. When looking at the endolithic microbial diversity of terrestrial dolostones, Horath et al. (2006) found the same cyanobacterial genera than the ones typically described on freshwater limestones substrates (Norris and Castenholz, 2006) while Sigler et al. (2003) concluded that the endolithic dolostone phototrophic community resembled other desiccation-tolerant endolithic communities. The question of whether there truly exists a specialized community associated with dolostone vs. limestone remains clearly open.

Our own data showed no specificity for substrate at family level, highlighting the need to analyze this at a phylogenetically deeper resolution. To do so, we analyzed how cyanobacterial OTUs were differentially represented in sample subsets from contrasted mineralogical substrates using the DESeq 2 method (Love et al., 2014). This method was developed to analyze RNA-seq datasets but can be used on any count matrix, such as an OTU table. This statistical framework is sensitive and precise and does not involve rarefying the dataset to an even sampling depth, so that the entire statistical power of the data is accounted for (McMurdie and Holmes, 2014). We used it to determine whether any given OTU is significantly differentially represented in a particular subset of samples sharing a common mineralogical substrate compared to another set. When comparing OTUs detected in samples which were mineralogically dominated by $\mathrm{Ca}$ carbonates (calcite or aragonite, $n=13$ ) with those that were dolomitic in nature $(\mathrm{CaMg}$ carbonate, $n=14$ ), we found 31 OTUs to be significantly enriched in Ca-carbonate substrates $\left(p<0.05\right.$; corresponding to $\log _{2}$ fold difference $>|2.83|$ ), while 22 preferred dolomite with $p<0.05$, out of 1039 cyanobacterial OTUs considered. Results suggest that substrate preferences are found when one looks at fine taxonomic resolution and that some likely euendoliths show such preference: Mastigocoleus testarum close relative NR_OTU193 prefers the Ca-carbonate pole ( $\log _{2}$ fold difference $=|3.4|$ ) while another possible euendolith NR_OTU741 belonging to the Pleurocapsales clearly prefers dolomite $\left(\log _{2}\right.$ fold difference $\left.=|1.7|\right)$. It is also clear that for most of the OTUs, either there is not sufficient resolution at the 16S rDNA level to detect it or, more parsimoniously, these OTUs represent taxa that can colonize various substrates. Many in this group of OTUs are not differentially represented on a particular substrate type, suggesting that they may be adventitious endoliths that do not bear the burden of boring into the substrate and can potentially colonize any substrate. However, at least some of these represent most likely euendoliths (NR_OTU4, OTU 351529 and OTU 842393) and still are not differentially represented with respect to the mineral phase they colonize. 
Using the same method, we then compared Ca-carbonatedominated samples $(n=14)$ to Ca-phosphate-dominated samples $(n=3)$. Although the paucity of phosphate samples restricted our statistical power, we were still able to identify 81 OTUs that were statistically significantly enriched on the phosphatic substrate $(p<0.05)$ side, while only 21 were enriched in carbonates $(p<0.05$; Fig. 5). This suggests an asymmetrical effect of carbonate vs. phosphate substrate types, the latter being a more powerful driver of differential abundance among cyanobacteria. However, in this case, the majority of OTUs, including some of the most abundant, were widespread across different substrate types. Mastigocoleus sp. (NR_OTU193) appeared clearly enriched in the carbonates $\left(\log _{2}\right.$ fold difference $\left.=|3.8|\right)$, while the other potential borers including the Pleurocapsales OTUs did not exhibit statistically significant differential abundance with substrate.

In all, these results suggest that some cyanobacteria do have a substrate preference and that these preferences sometimes occur among closely related clades (like NR_OTU193 and NR_OTU4), which do exhibit differential occurrence. These comparisons highlight the differential role of the cationic vs. the anionic mineral component. NR_OTU193 for instance showed a higher rate of occurrence when testing for both components, suggesting that it prefers calcium over magnesium in terms of cation and carbonate over phosphate as an anion. In contrast, NR_OTU741 only appeared differentially represented when the cationic part of the mineral varied. Finally, it is important to note that only a small fraction of the cyanobacterial community seems to be influenced by the substrate, $3.5 \%$ of the total number of species on average accounting for $16 \pm 4 \%$ of the total number of cyanobacterial sequences analyzed. These results are consistent with the idea that borers may be specialized, but ancillary endoliths are not. The substrate specialization of euendoliths may be due to the physiological requirements of excavation into specific mineral types. Future endolithic community metagenomic reconstructions and comparisons could aid in the identification of alternative pumps that may be specific to mineral types.

\subsection{Implications for the diversity of the boring mechanism and substrate-driven evolution of euendoliths}

A question that follows naturally from the previous findings is how such a substrate preference may relate to the physiological mechanism of boring. The model strain Mastigocoleus testarum $\mathrm{BC} 008$ is clearly specialized in the excavation of calcium carbonate through the uptake of calcium anions at the boring front and their active transport along the filament toward the surface (Garcia-Pichel et al., 2010; Garcia-Pichel, 2016). In culture, M. testarum strain BC008 could not bore into dolomite or magnesite. In agreement with this, the closest phylogenetic allies to this strain in our com- munities, NR_OTU193, did also show a higher rate of occurrence in calcium carbonates as compared to magnesium carbonate. Experiments with natural endolithic communities using calcium pump inhibitors have shown that the calciumbased mechanism is commonly at work in many localities but, at least in one case, boring was impervious to inhibition, pointing to the potential existence of mechanistic diversity (Ramírez-Reinat and Garcia-Pichel, 2012b). Because we could not detect preferential enrichment of bona fide euendoliths in the phosphate compared to the carbonate substrates, we must assume that the mineral anion is not a strong determinant of substrate choice in these communities. The boring mechanism described for M. testarum BC008 is in fact only dependent on the nature of the cation and could work in principle on calcium phosphates as well, and yet M. testarum strain $\mathrm{BC} 008$ did not bore into pure hydroxyapatite in the laboratory. These contrasted findings highlight that there must be factors other than the cationic part of the mineral determining the excavation ability of a particular strain and that the boring mechanism proposed for M. testarum strain BC008 might be incompletely described. Other mechanisms have been suggested to explain boring mechanism which have been invalidated for the model organism M. testarum strain but may prove themselves valuable for other taxa. The dissolution of carbonate mineral by acid excretion was proposed by Haigler (1969) and Golubic et al. (1984). This mechanism could involve spatial and temporal separation of photosynthesis vs. respiration by cyanobacteria or acid production as a byproduct of other heterotrophic bacteria activity (Garcia-Pichel, 2006). These hypotheses will need to be re-evaluated for other euendoliths as well as in natural communities.

\section{Conclusions}

An in-depth survey of endolithic microbial communities associated with Isla de Mona intertidal outcrops revealed a high diversity of organisms, comparable to those found in other benthic marine microbial communities such as the intertidal sediments and rock surfaces. These complex communities likely host various microbial metabolic guilds beyond oxygenic phototrophs described during more than a century of naturalist's descriptions. The analysis of the cyanobacterial community revealed the prominence of possible euendolithic species belonging to all the known microborers genera except perhaps Plectonema. Contrasting with results obtained at higher taxonomical level, evidence of substrate preference could only be detected among cyanobacteria at the OTU level and close relatives have different distribution patterns, arguing for the existence of boring mechanisms somewhat different to the one described in the model strain Mastigocoleus testarum. 


\section{Data availability}

The sequence dataset is publicly available: see Sect. 2.6 accession numbers.

\section{The Supplement related to this article is available online at doi:10.5194/bg-14-311-2017-supplement.}

Author contributions. Ferran Garcia-Pichel and Estelle Couradeau designed the experiment. Ferran Garcia-Pichel, Daniel Roush and Brandon Scott Guida performed the field work. The experimental work was done by Daniel Roush and Estelle Couradeau. Estelle Couradeau analyzed the results and Estelle Couradeau and Ferran Garcia-Pichel prepared the manuscript with contribution from all co-authors.

Acknowledgement. The authors would like to thank the Goldwater Materials Science Facility for their support in sample preparation and analysis. The authors would like to acknowledge Christophe Thomazo for his contribution to the "Euendolight" project and Purificación López-García for providing the Alchichica samples. This work was funded by the NSF Geobiology and Low-Temperature Geochemistry Program, grant 1224939, awarded to Ferran Garcia-Pichel and by the Marie Skłodowska-Curie IOF program, "Euendolight" grant, awarded to Estelle Couradeau.

Edited by: S. Bouillon

Reviewed by: two anonymous referees

\section{References}

Acton, E.: On A New Penetrating Alga, New Phytol., 15, 97-103, 1916.

Al-Thukair, A. A.: Calculating boring rate of endolithic cyanobacteria Hyella immanis under laboratory conditions, Int. Biodeter. Biodegr., 65, 664-667, 2011.

Al-Thukair, A. A. and Golubic, S.: Five new Hyella species from the Arabian Gulf, Algol. Stud. für Hydrobiol. Hydrobiol. Suppl. Vol., 64, 167-197, 1991.

Al-Thukair, A. A., Golubić, S., and Rosen, G.: New endolithic cyanobacteria from the Bahama bank and the Arabian gulf: Hyella racemus sp. nov., J. Phycol., 30, 764-769, 1994.

Bachmann, E.: Kalklösende Algen, Ber. Dtsch. Bot. Ges., 33, 4557, 1915.

Batters, E. A. L.: On Conchocelis, a new genus of perforating algae, Phycol. Mem., 1, 25-29, 1892.

Baumgartner, L. K. K., Reid, R. P. P., Dupraz, C., Decho, a. W. W., Buckley, D. H. H., Spear, J. R. R., Przekop, K. M. M., and Visscher, P. T. T.: Sulfate reducing bacteria in microbial mats: Changing paradigms, new discoveries, Sediment. Geol., 185, 131-145, 2006.
Bonar, L.: An Unusual Ascomycete In The Shells Of Marine Animals, University of California Press, University of California Publ. Botany, 1942.

Bornet, E. and Flahault, C.: Note sur deux nouveaux genres d'algues perforantes, J. Bot., 10, 161-165, 1888.

Briggs, R. P.: Economic Geology of the Isla de Mona quadrangle, Puerto Rico, 1959.

Briggs, R. P. and Seiders, V. M.: Geologic map of the Isla De Mona quadrangle, Puerto Rico, 1972.

Brito, Â., Ramos, V., Seabra, R., Santos, A., Santos, C. L., Lopo, M., Ferreira, S., Martins, A., Mota, R., Frazão, B., Martins, R., Vasconcelos, V., and Tamagnini, P.: Culture-dependent characterization of cyanobacterial diversity in the intertidal zones of the Portuguese coast: A polyphasic study, Syst. Appl. Microbiol., 35, 110-119, 2012.

Budd, D. A. and Perkins, R. D.: Bathymetric zonation and paleoecological significance of microborings in Puerto Rican shelf and slope sediments, J. Sediment. Petrol., 50, 881-984, 1980.

Campbell, S. E.: The modern distribution and geological history of calcium carbonate boring microorganisms, Biominer. Biol. Met. Accumul., 1983.

Caporaso, J. G., Kuczynski, J., Stombaugh, J., Bittinger, K., Bushman, F. D., Costello, E. K., Fierer, N., Peña, A. G., Goodrich, J. K., Gordon, J. I., Huttley, G. A., Kelley, S. T., Knights, D., Koenig, J. E., Ley, R. E., Lozupone, C. A., Mcdonald, D., Muegge, B. D., Pirrung, M., Reeder, J., Sevinsky, J. R., Turnbaugh, P. J., Walters, W. A., Widmann, J., Yatsunenko, T., Zaneveld, J., and Knight, R.: QIIME allows analysis of highthroughput community sequencing data, Nat. Methods, 7, 335336, 2010.

Chacón, E., Berrendero, E., Garcia Pichel, F., Chacon, E., Berrendero, E., Pichel, F. G., Chacón, E., Garcia Pichel, F., Berrendero, E., and Pichel, F. G.: Biogeological signatures of microboring cyanobacterial communities in marine carbonates from Cabo Rojo, Puerto Rico, Sediment. Geol., 185, 215-228, 2006.

Chazottes, V., Le Campion-Alsumard, T., and Peyrot-Clausade, M.: Bioerosion rates on coral reefs: Interactions between macroborers, microborers and grazers (Moorea, French Polynesia), Palaeogeogr. Palaeocl., 113, 189-198, 1995.

Chodat, R.: Sur les algues perforantes d'eau douce. Etudes de biologie lacustre, Bull. l'Herbier Boissier, 6, 431-476, 1898.

Cockell, C. S. and Herrera, A.: Why are some microorganisms boring?, Trends Microbiol., 16, 101-106, 2008.

Couradeau, E., Benzerara, K., Moreira, D., Gérard, E., Kaźmierczak, J., Tavera, R., López-García, P., Gerard, E., Kazmierczak, J., Tavera, R., and Lopez-Garcia, P.: Prokaryotic and Eukaryotic Community Structure in Field and Cultured Microbialites from the Alkaline Lake Alchichica (Mexico), edited by: Gilbert, J. A., PLoS One, 6, e28767, doi:10.1371/journal.pone.0028767, 2011.

Couradeau, E., Karaoz, U., Lim, H. C., Nunes da Rocha, U., Northen, T., Brodie, E., and Garcia-Pichel, F.: Bacteria increase arid-land soil surface temperature through the production of sunscreens, Nat. Commun., 7, 10373, doi:10.1038/ncomms10373, 2016.

Crits-Christoph, A., Robinson, C. K., Ma, B., Ravel, J., Wierzchos, J., Ascaso, C., Artieda, O., Souza-Egipsy, V., Casero, M. C., and DiRuggiero, J.: Phylogenetic and Functional Substrate Specificity for Endolithic Microbial Communities in Hyper-Arid Environments, Front. Microbiol., 7, 1-15, 2016. 
Debenport, S. J., Assigbetse, K., Bayala, R., Chapuis-Lardy, L., Dick, R. P., and McSpadden Gardener, B. B.: Association of shifting populations in the root zone microbiome of millet with enhanced crop productivity in the Sahel Region (Africa), Appl. Environ. Microbiol., 81, 2841-2851, 2015.

De la Torre, J. R., Goebel, B. M., Friedmann, E. I., and Pace, N. R.: Microbial Diversity of Cryptoendolithic Communities from the McMurdo Dry Valleys, Antarctica, Appl. Environ. Microbiol., 69, 3858-3867, 2003.

Duerden, J. E.: Boring algae as agents in the disintegration of corals, Bull. Am. Museum Nat. Hist., 16, 1902.

Duncan, P. M.: On Some Thallophytes Parasitic within Recent Madreporaria, P. R. Soc. A, 25, 238-257, 1876.

Dupraz, C. and Visscher, P. T.: Microbial lithification in marine stromatolites and hypersaline mats, Trends Microbiol., 13, 429-438, 2005.

Dupraz, C., Reid, R. P., Braissant, O., Decho, A. W., Norman, R. S., and Visscher, P. T.: Processes of carbonate precipitation in modern microbial mats, Earth-Sci. Rev., 96, 141-162, 2009.

Edgar, R. C.: Search and clustering orders of magnitude faster than BLAST, Bioinformatics, 26, 2460-2461, 2010.

Ercegovic, A.: La végétation des lithophytes sur les calcaires et les dolomites en Croatie, Acta Bot., 1, 64-114, 1925.

Ercegovic, A.: Tri nova roda litofiskih cijanoiceja sa jadranske obale, Acta Bot., 2, 78-84, 1927.

Ercegovic, A.: Sur quelques types peu connus des Cyanophycées lithophytes, Arch Protistenkd, 71, 361-376, 1930.

Foster, J. S., Green, S. J., Ahrendt, S. R., Golubic, S., Reid, R. P., Hetherington, K. L., and Bebout, L.: Molecular and morphological characterization of cyanobacterial diversity in the stromatolites of Highborne Cay, Bahamas, Isme J., 3, 573-587, 2009.

Frank, E. F., Mylroie, J., Troester, J., Calvin Alexander, E. J. , and Carew, J. L.: Karst development and speleogenesis, Isla de Mona, Puerto Rico, J. Cave Karst Stud., 60, 73-83, 1998.

Frémy, P.: Les algues perforantes, Mémoire la Société Natl. des Sci. Nat. Mathématiques Cherbg., 42, 275-300, 1936.

Frémy, P.: Cyanophycées et Chlorophycées perforantes (de la mer Rouge), Bull. la Société linnéenne Normandie, Mém. N.S., 1, 16-33, 1941.

Friedmann, E. I., Hua, M., and Ocampo-Friedmann, R.: Terraforming mars?: dissolution of carbonate rocks by Cyanobacteria, J. Br. Interplanet. Soc., 43, 291-292, 1993.

Garcia-Pichel, F.: Plausible mechanisms for the boring on carbonates by microbial phototrophs, Sediment. Geol., 185, 205-213, 2006.

Garcia-Pichel, F., Ramirez-Reinat, E., Gao, Q. J., Ramírez-Reinat, E., and Gao, Q. J.: Microbial excavation of solid carbonates powered by P-type ATPase-mediated transcellular $\mathrm{Ca}(2+)$ transport, P. Natl. Acad. Sci. USA, 107, 21749-21754, 2010.

Gektidis, M.: Development of microbial euendolithic communities: The influence of light and time, B. Geol. Soc. Denmark, 45, 147150, 1999.

Ghirardelli, L. A.: Endolithic Microorganisms in Live and Dead Thalli of Coralline Red Algae (Corallinales, Rhodophyta) in the Northern Adriatic Sea, Acta Geologica Hispanica, 37, 53-60, 2002.

Golubic, S.: Distribution, Taxonomy, and Boring Patterns of Marine Endolithic Algae, Integr. Comp. Biol., 9, 747-751, 1969.
Golubic, S. and Campion-Alsumard, T.: Boring behavior of marine blue-green algae Mastigocoleus testarum Lagerheim and Kyrtuthrix dalmatica Ercegović, as a taxonomic character, Schweiz. Z. Hydrol., 35, 157-161, 1973.

Golubic, S. and Lee, S. J.: Early cyanobacterial fossil record: preservation, palaeoenvironments and identification, Eur. J. Phycol., 34, 339-348, 1999.

Golubic, S., Friedmann, E. I., and Schneider, J.: The lithobiontic ecological niche, with special reference to microorganisms, J. Sediment. Res., 51, 475-478, 1981.

Golubic, S., Campbell, S. E., Drobne, K., Cameron, B., Balsam, W. L., Cimerman, F., and Dubois, L.: Microbial endoliths: a benthic overprint in the sedimentary record, and a paleobathymetric cross-reference with Foraminifera, J. Paleontol., 58, 351-361, 1984.

Golubic, S., Al-Thukair, A. A., and Gektidis, M.: New euendolithic cyanobacteria from the Arabian Gulf and the Bahama Bank: Solentia sanguinea sp. nova, Algol. Stud. für Hydrobiol. Hydrobiol. Suppl. Vol., 83, 291-301, 1996.

Golubic, S., Seong-Joo, L., and Browne, K. M.: Cyanobacteria: Architects of Sedimentary Structures BT - Microbial Sediments, Springer Berlin Heidelberg, Berlin, Heidelberg, 57-67, 2000.

Grange, J. S., Rybarczyk, H., and Tribollet, A.: The three steps of the carbonate biogenic dissolution process by microborers in coral reefs (New Caledonia), Environ. Sci. Pollut. Res., 22, 13625-13637, 2015.

Guida, B. S. and Garcia-Pichel, F.: Extreme cellular adaptations and cell differentiation required by a cyanobacterium for carbonate excavation, P. Natl. Acad. Sci. USA, 113, 5712-5717, doi:10.1073/pnas.1524687113, 2016.

Haigler, S. A.: Boring mechanism of Polydora websteri inhabiting Crassostrea virginica, Am. Zool., 9, 821-828, 1969.

Hoffmann, D., Maldonado, J., Wojciechowski, M. F., and GarciaPichel, F.: Hydrogen export from intertidal cyanobacterial mats: Sources, fluxes and the influence of community composition, Environ. Microbiol., 17, 3738-3753, 2015.

Horath, T. and Bachofen, R.: Molecular characterization of an endolithic microbial community in dolomite rock in the central Alps (Switzerland), Microb. Ecol., 58, 290-306, 2009.

Horath, T., Neu, T. R., and Bachofen, R.: An endolithic microbial community in dolomite rock in central Switzerland: characterization by reflection spectroscopy, pigment analyses, scanning electron microscopy, and laser scanning microscopy, Microb. Ecol., 51, 353-64, 2006.

Jobb, G., von Haeseler, A., and Strimmer, K.: TREEFINDER: a powerful graphical analysis environment for molecular phylogenetics, BMC Evol. Biol., 4, 18, 2004.

Jones, B.: The role of microorganisms in phytokarst development on dolostones and limestones, Grand Cayman, British West Indies, Can. J. Earth Sci., 26, 2204-2213, 1989.

Kaehler, S. and McQuaid, C. D.: Lethal and sub-lethal effects of phototrophic endoliths attacking the shell of the intertidal mussel Perna perna, Mar. Biol., 135, 497-503, 1999.

Katoh, K., Kuma, K., Toh, H., and Miyata, T.: MAFFT version 5: improvement in accuracy of multiple sequence alignment, Nucl. Acid. Res., 33, 511-518, 2005.

Kölliker, A.: On the frequent occurrence of vegetable parasites in the hard structures of animals, P. R. Soc. A, 10, 95-99, 1859. 
Le Campion-Alsumard, T. and Golubic, S.: Ecological and taxonomic relationships between euendolithic cyanophytes Hormathonema and Solentia, Algol. Stud. für Hydrobiol. Hydrobiol. Suppl. Vol., 38-39, 115-118, 1985.

Le Campion-Alsumard, T., Golubic, S., and Hutchings, P.: Microbial endoliths in skeletons of live and dead corals: Porites lobata (Moorea, French Polynesia), Oceanogr. Lit. Rev., 9, 781, 1995.

Le Campion-Alsumard, T., Golubic, S., and Pantazidou, A.: On the euendolithic genus Solentia Ercegovic (Cyanophyta/Cyanobacteria), Algol. Stud. für Hydrobiol. Hydrobiol. Suppl. Vol., 83, 107-127, 1996.

Lehmann, E.: Über Hyella balani nov. spec, Nyt Mag. Naturvidenskap, 41, 77-87, 1903.

Love, M. I., Huber, W., and Anders, S.: Moderated estimation of fold change and dispersion for RNA-seq data with DESeq2, Genome Biol., 15, 1-34, 2014.

MacIntyre, I. G., Prufert-Bebout, L., and Reid, R. P.: The role of endolithic cyanobacteria in the formation of lithified laminae in Bahamian stromatolites, Sedimentology, 47, 915-921, 2000.

May, J. A. and Perkins, R. D.: Endolithic infestation of carbonate substrates below the sediment-water interface, J. Sediment. Res., 49, 357-377, doi:10.1306/212F7748-2B24-11D78648000102C1865D, 1979.

McDonald, D., Price, M. N., Goodrich, J., Nawrocki, E. P., DeSantis, T. Z., Probst, A., Andersen, G. L., Knight, R., and Hugenholtz, P.: An improved Greengenes taxonomy with explicit ranks for ecological and evolutionary analyses of bacteria and archaea, ISME J., 6, 610-618, 2012.

McMurdie, P. J. and Holmes, S.: Waste Not, Want Not: Why Rarefying Microbiome Data Is Inadmissible, edited by: McHardy, A. C., PLoS Comput. Biol., 10, e1003531, 2014.

Mobberley, J. M., Ortega, M. C., and Foster, J. S.: Comparative microbial diversity analyses of modern marine thrombolitic mats by barcoded pyrosequencing, Environ. Microbiol., 14, 82-100, 2011.

Nadson, G. A.: Les algues perforantes de la Mer Noire, Comptes rendus l'Académie des Sci., 184, 896, 1927.

Nadson, G. A.: Contribution à l'étude des algues perforantes, I: La dissociation du thalle et la polymorphisme chez les algues perforantes "Hyella" et "Mastigocoleus“, Bull. USSR Acad. Sci., 7, 833-845, 1932.

Norris, T. B. and Castenholz, R. W.: Endolithic photosynthetic communities within ancient and recent travertine deposits in Yellowstone National Park, FEMS Microbiol. Ecol., 57, 470-483, 2006.

Nübel, U., GarciaPichel, F., Muyzer, G., and Garcia-pichel, F.: PCR Primers To Amplify 16S rRNA Genes from Cyanobacteria, Appl. Environ. Microbiol., 63, 3327-3332, 1997.

Nübel, U., Garcia-Pichel, F., Kuhl, M., and Muyzer, G.: Quantifying microbial diversity: Morphotypes, 16S rRNA genes, and carotenoids of oxygenic phototrophs in microbial mats, Appl. Environ. Microbiol., 65, 422-430, 1999.

Pantazidou, A., Louvrou, I., and Economou-Amilli, A.: Euendolithic shell-boring cyanobacteria and chlorophytes from the saline lagoon Ahivadolimni on Milos Island, Greece, Eur. J. Phycol., 41, 189-200, 2006.

Perkins, R. D. and Tsentas, C. I.: Microbial infestation of carbonate substrates planted on the St. Croix shelf, West Indies, Geol. Soc. Am. B., 87, 1615, 1976.
Peyrot-Clausade, M., Le Campion-Alsumard, T., Hutchings, P., Le Campion, J., Payri, C., and Fontaine, M. C.: Initial bioerosion and bioaccretion on experimental substrates in high island and atoll lagoons (French Polynesia), Oceanol. Acta, 18, 531-541, 1995.

Philippe, H.: MUST, a computer package of management utilities for sequences and trees, Nucl. Acid. Res., 21, 5264-5272, 1993.

Pitombo, L. M., do Carmo, J. B., de Hollander, M., Rossetto, R., López, M. V., Cantarella, H., and Kuramae, E. E.: Exploring soil microbial 16S rRNA sequence data to increase carbon yield and nitrogen efficiency of a bioenergy crop, GCB Bioenergy, 8, 867879, doi:10.1111/gcbb.12284, 2015.

Purdy, E. G. and Kornicker, L. S.: Algal disintegration of Bahamian limestone coasts, J. Geol., 66, 97-99, 1958.

Ramírez-Reinat, E. L. and Garcia-Pichel, F.: Characterization of a Marine Cyanobacterium That Bores Into Carbonates and the Redescription of the Genus Mastigocoleus, J. Phycol., 48, 740-749, 2012a.

Ramírez-Reinat, E. L. and Garcia-Pichel, F.: Prevalence of $\mathrm{Ca}^{2+}$ ATPase-mediated carbonate dissolution among cyanobacterial euendoliths, Appl. Environ. Microbiol., 78, 7-13, 2012b.

Reid, R. P., Visscher, P. T., Decho, A. W., Stolz, J. F., Bebout, B. M., Dupraz, C., Macintyre, L. G., Paerl, H. W., Pinckney, J. L., Prufert-Bebout, L., Steppe, T. F., DesMarais, D. J., MacIntyre, I. G., Paerl, H. W., Pinckney, J. L., Prufert-Bebout, L., Steppe, T. F., and DesMarais, D. J.: The role of microbes in accretion, lamination and early lithification of modern marine stromatolites, Nature, 406, 989-992, 2000.

Roesch, L. F. W., Fulthorpe, R. R., Riva, A., Casella, G., Km, A., Kent, A. D., Daroub, S. H., Camargo, F. A. O., Farmerie, W. G., and Triplett, E. W.: Pyrosequencing Enumerates and Contracts Soil Microbial Diversity, ISME J., 1, 283-290, 2007.

Sartoretto, S.: Bioerosion of Mediterranean "coralligene" concretions by boring organisms: assay of quantificaition of processes, C. R. Acad. Sci. Paris, 327, 839-844, 1998.

Schneider, J.: Biokarst on limestone coasts, morphogenesis and sediment production, Deep-Sea Res. Pt. II, 30, 45-63, 1983.

Sigler, W. V, Bachofen, R., and Zeyer, J.: Molecular characterization of endolithic cyanobacteria inhabiting exposed dolomite in central Switzerland, Environ. Microbiol., 5, 618-627, 2003.

Soudry, D. and Nathan, Y.: Microbial infestation: A pathway of fluorine enrichment in bone apatite fragments (Negev phosphorites, Israel), Sediment. Geol., 132, 171-176, 2000.

Torunski, H.: Biological erosion and its significance for the morphogenesis of limestone coasts and for nearshore sedimentation (Northern Adriatic), Senckenbergiana maritima, 11, 193-265, 1979.

Tribollet, A.: Dissolution of dead corals by euendolithic microorganisms across the northern Great Barrier Reef (Australia), Microb. Ecol., 55, 569-80, 2008.

Tribollet, A. and Payri, C.: Bioerosion of the coralline alga Hydrolithon onkodes by microborers in the coral reefs of Moorea, French Polynesia, Oceanol. Acta, 24, 329-342, 2001.

Tribollet, A., Langdon, C., Golubic, S., and Atkinson, M.: Endolithic microflora are major primary producers in dead carbonate substrates of Hawaiian coral reefs, J. Phycol., 42, 292-303, 2006. 
Tribollet, A., Godinot, C., Atkinson, M., and Langdon, C.: Effects of elevated $p \mathrm{CO}_{2}$ on dissolution of coral carbonates by microbial euendoliths, Global Biogeochem. Cy., 23, 1-7, 2009.

Trudgill, S. T. T.: Bioerosion of intertidal limestone, Co. Clare, Eire - 3: Zonation, process and form, Mar. Geol., 74, 111-121, 1987.

Tudhope, A. W. and Risk, M. J.: Rate of dissolution of carbonate sediments by microboring organisms, Davies Reef, Australia, J. Sediment. Petrol., 55, 440-447, 1985.

Underwood, C. J., Mitchell, S. F., and Veltkamp, C. J.: Microborings in mid-Cretaceous fish teeth, Proc. Yorksh. Geol. Soc., 52, 269-274, 1999.

Vogel, K., Gektidis, M., Golubic, S., Kiene, W. E., and Radtke, G.: Experimental studies on microbial bioerosion at Lee Stocking Island, Bahamas and One Tree Island, Great Barrier Reef, Australia: implications for paleoecological reconstructions, Lethaia, 33, 190-204, 2000.

Wade, B. D. and Garcia-Pichel, F.: Evaluation of DNA extraction methods for molecular analyses of microbial communities in modern calcareous microbialites, Geomicrobiol. J., 20, 549-561, 2003.
Walker, J. J. and Pace, N. R.: Phylogenetic Composition of Rocky Mountain Endolithic Microbial Ecosystems, Appl. Environ. Microbiol., 73, 3497-3504, 2007.

Walker, J. J., Spear, J. R., and Pace, N. R.: Geobiology of a microbial endolithic community in the Yellowstone geothermal environment, Nature, 434, 1011-1014, 2005.

Wisshak, M., Tribollet, A., Golubic, S., Jakobsen, J., and Freiwald, A.: Temperate bioerosion: ichnodiversity and biodiversity from intertidal to bathyal depths (Azores), Geobiology, 9, 492-520, 2011.

Zhang, X. and Pratt, B. R.: Microborings in Early Cambrian phosphatic and phosphatized fossils, Palaeogeogr. Palaeocl., 267, 185-195, 2008. 